\title{
Anti-dengue serotype-2 activity effect of Sambucus nigra leaves-and flowers-derived compounds
}

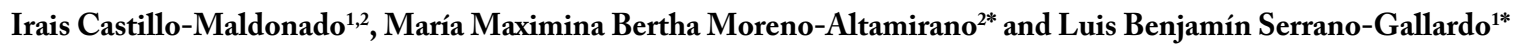 \\ ${ }^{1}$ Laboratorio de Fitofarmacología, Centro de Investigación Biomédica, Facultad de Medicina, Universidad Autónoma de Coahuila, Gregorio A. García s/n, \\ Torreón, Coahuila, México \\ ${ }^{2}$ Departamento de Inmunología, Escuela Nacional de Ciencias Biológicas, Instituto Politécnico Nacional, Carpio y Plan de Ayala s/n, Col. Casco de Santo Tomás, \\ Ciudad de Mexico City, Mexico
}

\begin{abstract}
Background: Dengue is the most widespread arthropod-borne viral infection in humans. Protective vaccines and effective anti-dengue treatments are still missing. Ancient knowledge on the antimicrobial properties of plants provides a powerful source for new antiviral drugs. Sambucus nigra, widely distributed in Mexico, has long been used in traditional medicine, including for some viral infections.

Objective: The purpose of this study was to evaluate in vitro if $S$. nigra methanolic extracts have anti-dengue properties.

Method: The antiviral activity was assayed under three experimental conditions: (a) addition of methanolic extracts $1 \mathrm{~h}$ before dengue virus serotype-2 (DENV-2) was added to cells; (b) cell pre-incubation with DENV-2, $1 \mathrm{~h}$ before adding extracts; and (c) pre-incubation of DENV-2 with the extracts for $1 \mathrm{~h}$, and then adding this mix to the cells (BHK-21 and VERO). After three days of incubation, infection was evaluated by measuring the cytopathic effect, the NS-1 viral protein production, and DENV-2 envelope protein assessment.
\end{abstract}

Results: $S$. nigra methanolic extracts from both, leaves and flowers, exhibited anti-DENV-2 activity at $400 \mu \mathrm{g} / \mathrm{mL}$, particularly when DENV-2 was pre-incubated with the extracts before being added to cell cultures.

\section{Introduction}

Dengue is caused by any of four dengue virus serotypes (DENV$1,-2,-3$, or -4$)$. Every year an estimated of 390 million people are infected worldwide [1]. DENV is a Flavivirus, its positive singlestranded RNA encodes for 10 proteins [2]. DENV is transmitted to humans by female Aedes aegypti and Aedes albopictus mosquitoes [3]. The clinical manifestations of dengue were re-classified by the World Health Organization in 2009 [4]. Despite considerable research aimed at the development of effective anti-dengue therapeutic drugs or vaccines, up to date a worldwide successful vaccination program is still missing. However, anti-dengue vaccine candidates, such as Dengvaxia are currently under clinical trials [5]. The first tetravalent recombinant dengue vaccine was registered in Mexico, and licensed in Brazil, El Salvador, and the Philippines in 2015. An interesting alternative approach for dengue treatment, is the use of medicinal plant-derived compounds, since plant extracts have been therapeutically used since ancient times, and, in many instances, have proven to be effective [69]. Some medicinal plants have shown strong antiviral activity, and inhibition of the replicative cycle, both for DNA and RNA viruses [10]. Research on plants against dengue virus is scarce [11-13]. Even the World Health Organization (WHO) has advocated that in DENV endemic areas, traditional medicine should be considered with the purpose of identifying safe and effective antiviral therapeutics.

Sambucus nigra is a Caprifoliaceae or honey suckle family plant, widely distributed in the North of Mexico, its leaves, bark, flowers, and berries have all been used in traditional medicine, and berries have shown antiviral effect against influenza A and B, HIV, and Herpes simplex-1 viruses, as well as against a pathogenic chicken coronavirus [14-19].
The present study was aimed at screening and assessing of the antidengue virus activity of methanolic extracts of leaves and flowers of $S$. nigra.

\section{Methods}

S. nigra flowers and leaves were collected from the rural municipality of Nazas, Durango, Mexico (latitude between $24^{\circ} 57^{\prime}$ and $25^{\circ} 36^{\prime} 39^{\prime \prime}$ $\mathrm{N}$, longitude between $103^{\circ} 46^{\prime}$ and $104^{\circ} 24^{\prime} 50^{\prime \prime} \mathrm{W}$, altitude between 1100 and $2500 \mathrm{~m}$ above sea level), following the good manufacturing practices, proposed by the World Health Organization (WHO, 2003) [20]. Botanical authentication was performed by the Escuela de Biología de la Universidad Juárez, Durango, Mexico, and deposited at the herbarium of the same University, under the taxonomical serial number 525079. Leaves and flowers were air-dried at room temperature and then ground into a fine powder. Methanol (Sigma

Correspondence to: Dr. Sc. María Maximina Bertha Moreno-Altamirano, Laboratorio de Inmunorregulación, Departamento de Inmunología, Escuela Nacional de Ciencias Biológicas, Instituto Politécnico Nacional, Carpio y Plan de Ayala s/n, Col. Casco de Santo Tomás, C.P. 11340, Ciudad de México, México, Tel: +52(871) 7176404; E-mail: bertha.moreno.altamirano@gmail.com, morsan846698716@aol.com

Dr. Sc. Luis Benjamín Serrano-Gallardo, Laboratorio de Farmacología, Centro de Investigación Biomédica, Escuela, de Medicina, Universidad de Coahuila, Gregorio A. García 198, Centro, 27000, Torreón, Coahuila, México, Tel: +52(871) 7176404; E-mail: serranoluis56@gmail.com

Key words: dengue virus, Sambucus nigra, anti-viral activity

Received: June 13, 2017; Accepted: June 28, 2017; Published: June 30, 2017 
Chemical Co. St Louis, MO, USA) was used as the extraction solvent. The powder was soaked in methanol at a ratio of 1:10 (w/v) for $24 \mathrm{~h}$. The mixture was filtered with a Whatman1 filter paper (GE Healthcare Life Sciences), and concentrated in a rotary evaporator under reduced pressure. Crude extracts were taken to complete dryness in a hot air oven at a temperature lower than $40^{\circ} \mathrm{C}$. The dry extracts were stored at $4^{\circ} \mathrm{C}$ in amber bottles, as described by Zakaria, et al. [21].

Viability was assayed for BHK-21 and VERO cells; $300 \times 10^{3}$ cells/ well were cultured in a 96-wells plate, in medium alone (negative control), with DENV-2 or with the methanolic extracts at 50,100,200, $300,400,800$, and $1600 \mu \mathrm{g} / \mathrm{mL}$ for BHK-21 cells; and at 50, 100, 200, $300,400,800 \mu \mathrm{g} / \mathrm{mL}$ for VERO cells, then incubated at $37^{\circ} \mathrm{C}$ and $5 \% \mathrm{CO}_{2}$ in a humidified incubator. After 3 days (for BHK-21 cells) or 5 days (for VERO cells), $10 \mu \mathrm{L}$ of Alamar Blue was added to each well and left for 2 h. After which, reduction of Alamar blue, as indicative of cells metabolic activity and therefore viability was assessed in a Fluoroskan Ascent FL Microplate Fluorometer (Thermo Scientific, MA, USA) at 540-570 nm and 580-610 $\mathrm{nm}$ excitation and emission wavelengths, respectively. The percentage of viability was calculated, taking the relative fluorescence units of cells cultured in medium alone as $100 \%$ viability. At $400 \mu \mathrm{g} / \mathrm{ml}$ of the extracts, cell viability was between $60 \%$ and $80 \%$. Therefore, this concentration was used to test the anti-DENV-2 activity.

Virus propagation and titration. Dengue virus-serotype 2 (NG strain) was propagated in C6/36 cells (ATCC). Titration was carried out by means of plaque assay, following Perea's protocol [22].

Sambucus nigra antiviral activity assessment. To test the antiviral activity of the methanolic extracts (leaves and flowers) of S. nigra, 0.5 $\mathrm{x} 10^{6}$ BHK-21 and VERO cells were seeded, separately, over cover slips in 12 -wells plates, cultured at $37^{\circ} \mathrm{C}$ and $5 \% \mathrm{CO}_{2}$ overnight. Cells or DENV-2 were incubated with the extract $(400 \mu \mathrm{g} / \mathrm{mL})$. Three different treatment protocols were applied as follows: (a) addition of the methanolic extract to cells $1 \mathrm{~h}$ before adding DENV-2; (b) cells pre-incubation with DENV-2 for $1 \mathrm{~h}$ before adding the leaf or flower methanolic extracts; and (c) pre-incubation of DENV-2 with the methanol extract for $1 \mathrm{~h}$, and then adding this mix to the cells. Cells cultured with medium alone were used as negative control, whereas cells cultured with DENV-2 were used as a control of infection. In all cases (except medium alone), cells were infected with $200 \times 10^{3}$ DENV2 particles.

Cells were cultured for a total of 5 days. Cell supernatants (250 $\mu \mathrm{L}$ ) were collected at 0,2 , and $3 \mathrm{~h}$, and at $1,2,3,4$, and 5 days postinfection, and stored at $-20^{\circ} \mathrm{C}$ for NS- 1 protein determination (DEN-2 replication), whereas cells, at the same time points, were used for the assessment of DENV envelope protein (intracellular DENV-2).

DENV-2 non-structural protein (NS-1) determination. DENV2-infected BHK-21 and VERO cells supernatants, collected at different time points post-infection were analyzed for non-structural protein (NS-1) by using the commercially available enzyme linked immunoassay-based Platelia Dengue NS1 AG kit (Bio-Rad, Hercules, CA, USA). following the technical insert, using $100 \mu \mathrm{L}$ of positive and negative controls from the kit, as well as the supernatants from each cell culture condition. Optical density was measured at 450/620 nm in a Multiskan ELISA plate reader (Thermo Scientific, Waltham, MA, USA). NS-1 concentration in each sample was calculated from an NS-1 standard curve (Fig. 4), following the Bio-Rad technical insert.

Indirect immunofluorescence assays. As a complementary approach to evaluate the antiviral activity of the $S$. nigra methanolic extracts, indirect immunofluorescence assays for the detection of intracellular DENV-2 were carried out on BHK-21 and VERO cells and treated as described in the antiviral assessment section. Cells were fixed with ice-cold absolute methanol for $20 \mathrm{~min}$ and permeabilized with $0.3 \%$ Triton-X100, blocked for one hour at room temperature with $3 \%$ bovine serum albumin in PBS, and subsequently incubated overnight with anti-DENV envelope protein mouse moAb (Santa Cruz Biotechnology, Inc., Dallas, TX, USA) at $4^{\circ} \mathrm{C}$, followed by incubation with FITC-labeled anti-mouse IgG secondary antibody (Santa Cruz Biotechnology) and mounted in DAPI-containing Vectashield (Vector Laboratories, Burlingame, CA, USA). Cells were observed using an LSM5 Pascal confocal microscope (Carl Zeiss, Germany). Cell images were analyzed with the ImageJ software (NIH, USA). Mean fluorescent intensity (MFI) represents the relative amount of intracellular DENV envelope protein and therefore the relative amount of dengue virus.

\section{Statistical analysis}

To assess the effect of treatments on DENV-2 infection, Chi-square test and analyses of variance (ANOVA) were performed using the Graph Pad Prism 6 software (La Jolla, CA, USA), with 95\% confidence intervals. A p value of $<0.05$ was considered statistically significant.

\section{Results}

\section{BHK-21 and VERO cell viability after treatment with S. nigra leaves and flowers methanolic extract}

After 5 days in culture, cells in medium alone (negative control) showed no signs of cytotoxicity. Viability in those cells was regarded as $100 \%$. Treatment showed a negative correlation between extract concentration and cell viability. However, in all cases cell viability was between $60 \%$ and $80 \%$ when extract concentration was $400 \mu \mathrm{g} / \mathrm{mL}$ or less, as shown in Figure 1. Accordingly, the anti-DENV-2 activity of the extracts was assessed using this concentration.

DENV-2 propagation rendered $300 \mathrm{~mL}$ of viral stock. DENV-2 was titrated and stored at $-70^{\circ} \mathrm{C}$, until use. All experiments were carried out with the same viral stock.

Anti-DENV-2 activity analyses, showed that methanolic extracts rendered a protective effect against DENV-2 when cells were treated with the extracts before they were infected. Pre-treatment with $S$. nigra flowers was more protective than pre-treatment with $S$. nigra leaf extracts. However, pre-incubation of DENV-2 with either leaves or flowers, before infection, was the most effective way to protect cell monolayers (Figure 2).

These results were confirmed by assessment of DENV-2 NS-1 protein. Figure 3 shows the relative amount of NS-1 protein, expressed as O.D values, in the supernatants of both BHK-21 (empty bars) and VERO cells (filled bars).

To further evaluate the anti-viral effect of $S$. nigra extracts, the presence of intracellular DENV-2 viral particles was assessed by indirect immunofluorescence, using an anti-DENV envelope protein antibody and a fluorochrome-labeled secondary antibody. Results were observed through confocal microscopy. Fig 4 shows the mean fluorescence intensity (mean \pm standard deviation) of three independent experiments. The relative amount of intracellular DENV2 particles in cells that were treated with the mixture of DENV-2 with flowers or leaves extract was statistically lower than in cells treated with DENV-2 particles only $(\mathrm{p}<0.001)$.

The results here presented show that $S$. nigra leaf and flower methanolic extracts have anti-DENV-2 properties. Further studies are 
BHK-21
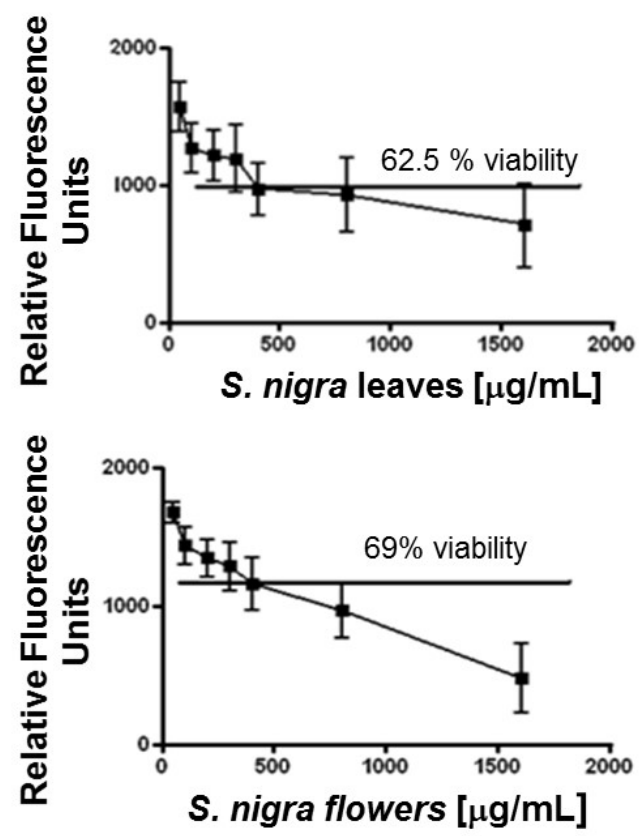

VERO

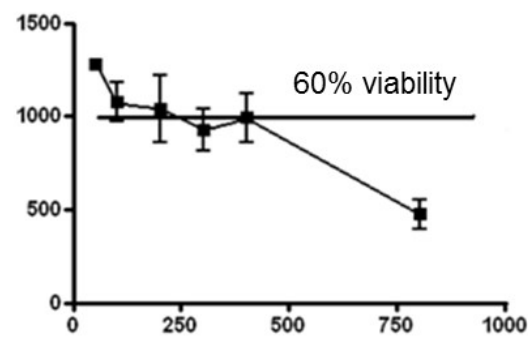

S. nigra leaves $[\mu \mathrm{g} / \mathrm{mL}]$

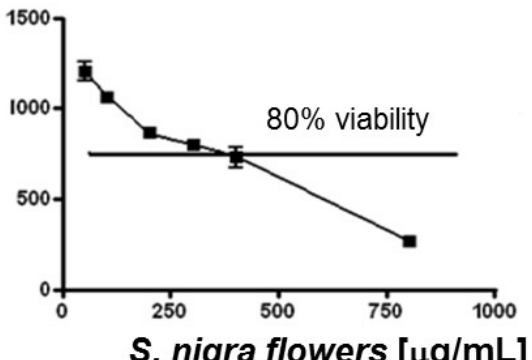

Figure 1. Viability of cells exposed to Sambucus nigra methabolic extracts. Cell viability was assessed in BHK-21, and VERO cells exposed to different concentrations of $S$. nigra flower and leaf methanolic extracts, by using the Alamar Blue assay. Relative fluorescence units for cells cultured in medium alone were considered as $100 \%$ viability. A negative correlation between extract concentration and cell viability was observed. At a concentration of $400 \mu \mathrm{g} / \mathrm{mL}$ there was a cell viability of $60-80 \%$.
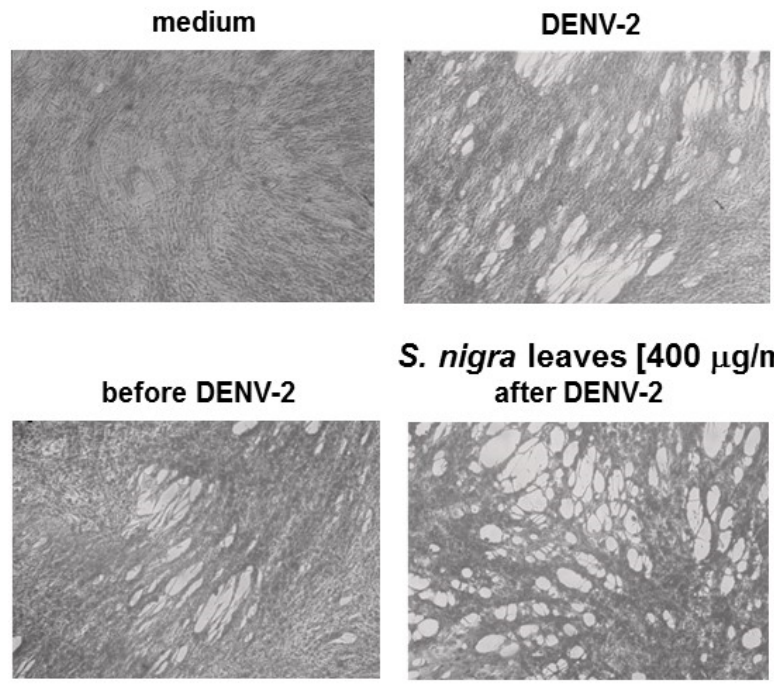

S. nigra leaves $[400 \mu \mathrm{g} / \mathrm{mL}]$ after DENV-2

pre-incubation with DENV-2
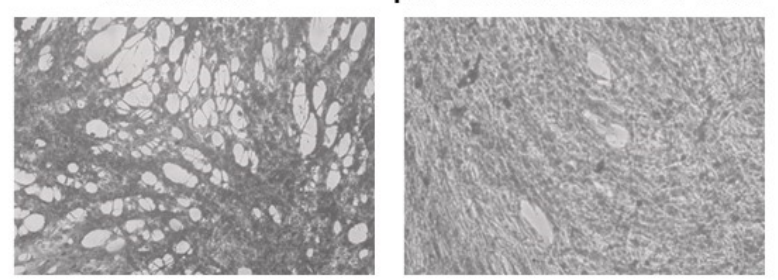

S. nigra flowers $[400 \mu \mathrm{g} / \mathrm{mL}]$
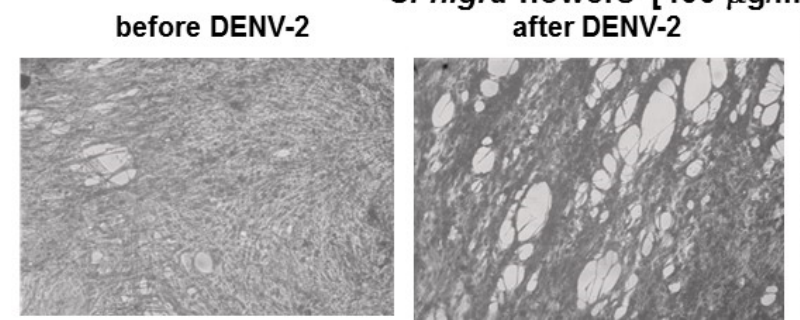

pre-incubation with DENV-2

Figure 2. Pre-incubation of DENV-2 with $\boldsymbol{S}$. nigra leaf and flower methanolic extract diminishes DENV-2-mediated cytopathic effect. BHK-21 cells were kept in medium alone, infected with DENV-2 virus, treated with methanolic extracts from leaves or flowers at a $400 \mu \mathrm{g} / \mathrm{ml}$ final concentration, before DENV-2, after DENV-2, or with a mixture of DENV-2 plus S. nigra extracts. The highest anti-viral effect was observed when DENV-2 was pre-incubated with the methanolic extracts before addition to cell cultures. 
required to isolate and characterize these compounds and to elucidate the precise mechanism of their anti-DENV-2 action.

\section{Discussion}

S. nigra was selected as a possible source of anti-DENV compounds based on its ethnopharmacological characteristics and known antiviral activity [23-25]. Other studies have addressed the anti-DENV activity of plant-derived compounds [26]. Although S. nigra has shown to have antiviral properties [19], the leaves and flowers of this plant have not been evaluated against the dengue virus.

S. nigra (Sauco, Elder) is rich in phenolic acids, flavonoids, catechins, and proanthocyanidins [27] and these compounds have shown anti-cancer, immune-stimulating, anti-bacterial, anti-allergic, anti-tussive, bronchodilatory, and anti-viral properties [28].

Preliminary phytochemical analysis of $S$. nigra methanolic extracts showed that they contain alkaloids, flavonoids and a noticeable amount of coumarins. Besides, brine shrimp (Artemia salina)-based toxicity bioassays showed that the $\mathrm{DL}_{50}$ for $S$. nigra leaf and flower extracts was higher than $1000 \mu \mathrm{g} / \mathrm{mL}$ (data no shown), all of which indicates a low toxicity, similar to that of methanolic extracts from other plants from northern Mexico, such as Tecomastans, Acacia farnesiana, Euphorbia antisiphylitica, and Fouquieria splendens [29].

In this study, cell viability of BHK-21 and VERO treated with $S$. nigra methanolic extracts was evaluated and, based on the results, a concentration of $400 \mu \mathrm{g} / \mathrm{mL}$ was used for all further biological assays because, at this concentration, cell viability was between $60 \%$ and $80 \%$ (Figs. 1). As a reference, it has been shown that treatment with $1200 \mu \mathrm{g}$ of $S$. nigra leaves $/ \mathrm{kg}$ of body weight has anti-depressant activity [30], and that $1000 \mu \mathrm{g} / \mathrm{mL}$ of elderberry flavonoids totally inhibit H1N1 infection in vitro [31].

DENV-2-induced cytopathic effect was evaluated on BHK-21 cells to determine the antiviral activity of $S$. nigra leaf and flower methanolic extracts; both of which proved to be protective against DENV-2, at a concentration of $400 \mu \mathrm{g} / \mathrm{mL}$ (Figure 2). These results are similar to those showing that $S$. nigra elderberry fruit-derived compounds have anti-human influenza A (H1N1) activity at a concentration of $252 \pm 34$ $\mu \mathrm{g} / \mathrm{mL}[31]$.

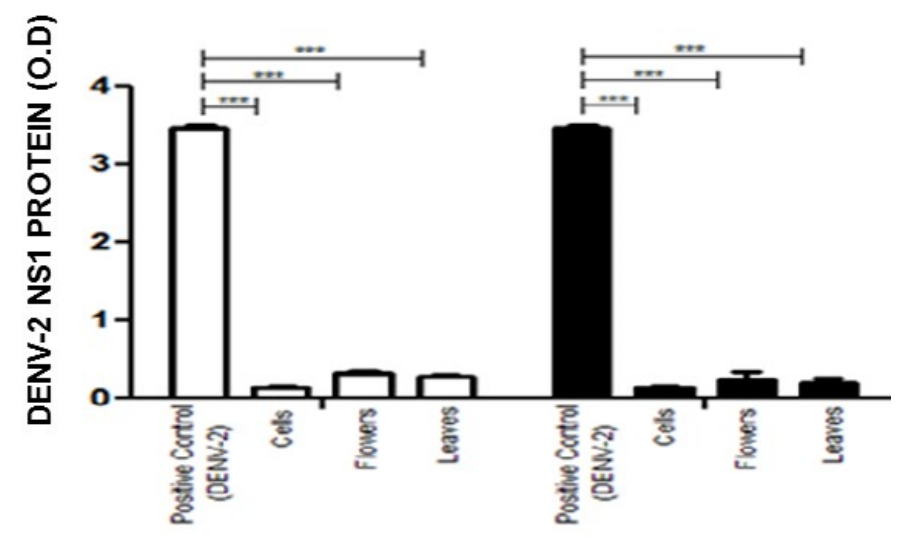

Figure 3. Anti-DENV-2 activity of methanolic leaf and flower extracts from $S$. nigra, as assessed by DENV-2 NS-1 synthesis. The antiviral activity of $S$. nigra flower and leaf methanolic extracts was evaluated on BHK-21 (empty bars) and VERO (filled bars) cells, by measuring the NS1 viral protein in the cell supernatants of cells + DENV-2; cells in medium alone; cells + flower extracts + DENV-2; and cells + flowers and leaves + DENV-2. Results are expressed as O.D. values, ${ }^{*} \mathrm{p}<0.001$.

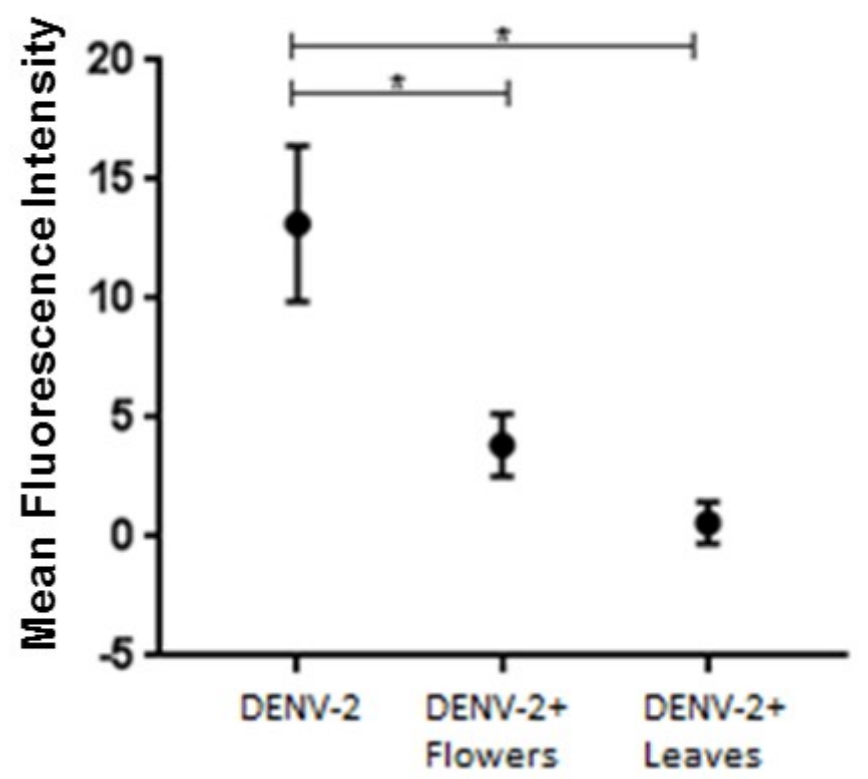

Figure 4. Anti-DENV-2 activity of flower and leaf methanolic extracts from $\boldsymbol{S}$. nigra, as assessed by DENV-2 envelope protein content. Anti-DENV-2 activity of $S$. nigra (A) flower and (B) leaf methanolic extracts was evaluated by infecting BHK-21 cells with $1.5 \times 10^{3}$ DENV-2 viral particles (positive control), and under conditions in which infected cells were also treated with the methanolic extracts, or in which DENV-2 was pre-incubated with the extracts, $1 \mathrm{~h}$ before addition to the cells. In all cases, infection was assessed by fluorescence-based anti-DENV envelope protein content within the cells, and confocal microscopy. Mean fluorescent intensity (MFI) is indicative of the relative amount of DENV-2 envelope protein and, therefore, of the extent of infection ${ }^{* * *} \mathrm{p}<0.001$.

The anti-viral effect of $S$. nigra has also been documented for an elder flowers infusion, which has activity against influenza and herpes simplex viruses [32], and S. nigra-derived flavonoids prevent $\mathrm{H} 1 \mathrm{~N} 1$ infection in vitro [31].

S. nigra methanolic extracts were evaluated in relation to the time at which they were added to the cell cultures. The maximum effect was achieved when DENV-2 was pre-incubated with the extracts for $1 \mathrm{~h}$ and then added to the cell cultures (Figure 2). This result was further confirmed by analyzing the synthesis of NS-1 protein (Figure 3 ), and the extent of intracellular DENV-2 (Figure 4). Similar results were reported by Ocazionez, et al. These authors found a reduced DENV plaque formation when DENV was incubated with Lippia alba or Lippia citriodora oil, before adsorption on cells, and they did not observe a viral inhibitory effect by addition of the oils after virus adsorption [26].

\section{Acknowledgment}

We thank Dr. F. Javier Sánchez-García for critical review of the manuscript.

\section{Competing interest}

The authors declare no conflict of interests.

\section{Funding information}

This work was financed by SIP20170708 granted to MMB MorenoAltamirano. I Castillo-Maldonado was the recipient of a CONACYT $312488 \mathrm{PhD}$ Scholarship y Fondo para promover el desarrollo de ciencia y tecnología, COECYT-Gobierno del estado de Coahuila (COAH-2011-C07-C31). 


\section{References}

1. Bhatt S, Gething PW, Brady OJ, Messina JP, Farlow AW, et al. (2013) The global distribution and burden of dengue. Nature 496: 504-507. [Crossref]

2. Guzman MG, Halstead SB, Artsob H, Buchy P, Farrar J, et al. (2010) Dengue: a continuing global threat. Nat Rev Microbiol 8: S7-16. [Crossref]

3. WHO (2015) Treatment, prevention and control global strategy for dengue prevention and control 2012-2020. World Health Organization.

4. WHO (2009) Dengue Guidelines for diagnosis, treatment, prevention and control. World Health Organization, Geneva, Switzerland.

5. http://www.who.int/immunization/research/development/dengue_vaccines/en/

6. De Sousa LR, Wu H, Nebo L, Fernandes JB, Da Silva MF, et al. (2015) Flavonoids as noncompetitive inhibitors of Dengue virus NS2B-NS3 protease: Inhibition kinetics and docking studies. Bioorg Med Chem 23: 466-470.

7. Sánchez I, Gómez-Garibay F, Taboada J, Ruiz BH (2000) Antiviral effect of flavonoids on the dengue virus. Phytother Res 14: 89-92. [Crossref]

8. Alché LE, Berra A, Veloso MJ, Coto CE (2000) Treatment with meliacine, a plant derived antiviral, prevents the development of herpetic stromal keratitis in mice. JMed Virol 61: 474-480.

9. Naithani R, Huma LC, Holland LE, Shukla D, McCormick DL, et al. (2008) Antiviral activity of phytochemicals: a comprehensive review. Mini Rev Med Chem 8: 11061133.

10. Mahmoudi M, Ebrahimzadeh MA, Dooshan A, Arimi A, Ghasemi N, et al. (2014) Antidepressant activities of Sambucus ebulus and Sambucus nigra. Eur Rev Med Pharmacol Sci 18: 3350-3353. [Crossref]

11. Muliawan SY, Kit LS, Devi S, Hashim O, Yusof R (2006) Inhibitory potential of Quercus lusitanica extract on dengue virus type 2 replication. Southeast Asian J Trop Med Public Health 37 Suppl 3: 132-135. [Crossref]

12. Carvalho Leite F, Da Silva Mello C, Gomez Fialho L (2016) Cissampelos sympodialis has anti-viral effect inhibiting dengue non-structural viral protein-1 and proinflammatory mediators. Braz J Pharmacog 28: 502-506.

13. Tang LI, Ling AP, Koh RY, Chye SM, Voon KG (2012) Screening of anti-dengue activity in methanolic extracts of medicinal plants. BMC Complement Altern Med 12 : 3. [Crossref]

14. Lust J (1974) The Herb Book. Benedict Lust Publications, Open library, Newe York.

15. Duke JA (2002) Handbook of Medicinal Herbs. (2nd Edn) Boca Raton: CRC Press.

16. Sahpira-Nahor O, Zakay-Rones Z, Mumcuoglu M (1995) The effects of Sambucol on HIV infection in vitro. Ann Israel Congress Microbiol pp: 6-7.

17. Morag AM, Mumcuoglu M, Baybikov T (1997) Inhibition of sensitive and acyclovirresistant HSV-1 strains by an elderberry extract in vitro. $Z$ Phytother 25: 97-98.
18. Zakay-Rones Z, Thom E, Wollan T, Wadstein J (2004) Randomized study of the efficacy and safety of oral elderberry extract in the treatment of influenza A and B virus infections. J Int Med Res 32: 132-140. [Crossref]

19. Chen C, Zuckerman DM, Brantley S (2014) Sambucus nigra extracts inhibit infectious bronchitis virus at an early point during replication. BMC Vet Res 10: 24.

20. WHO (2003) WHO guideline on good agricultural and collection practices (GACP) for medicinal plants. World Health Organization pp. 1-72.

21. Zakaria ZA, Mohamed AM, Jamil NS, Rofiee MS, Hussain MK, et al. (2011) In vitro antiproliferative and antioxidant activities of the extracts of Muntingia calabura leaves. Am J Chin Med 39: 183-200.

22. Perea-Martínez L, Moreno-Sandoval HN, Moreno-Altamirano MM, Salas-Rojas M, García-Flores MM, et al. (2013) Experimental infection of Artibeus intermedius bats with serotype-2 dengue virus. Comp Immunol Microbiol Infect Dis 36:193-198.

23. Klawikkan N, Nukoolkarn V, Jirakanjanaki N, Yoksan S, Thirapanmethee K (2011) Effect of Thai Medicinal Plant against Dengue Virus in vitro. Mahidol Univ J Phar Sci 38:13-18.

24. Vlachojannis JE, Cameron M, Chrubasik SA (2010) Systematic review on the sambuci fructus effect and efficacy profiles. Phytother Res 24:1-8.

25. DuymuÅŸ HG, GÃ Iger F, BaÅŸer KH (2014) In vitro antioxidant properties and anthocyanin compositions of elderberry extracts. Food Chem 155: 112-119. [Crossref]

26. Ocazionez RE, Meneses R, Torres FA, Stashenko E. Virucidal activity of Colombian Lippia essential oils on dengue virus replication in vitro. Mem Inst Oswaldo Cruz 2010; 105: 304-309.

27. Veberic R, Jakopic J, Stampar F, Schmitzer V (2009) European elderberry (Sambucus nigra L.) rich in sugars, organic acids, anthocyanins and selected polyphenols. Food Chem 114: 511-515.

28. Halama A, KuliÅ ski M, Librowski T, LochyÅ ski S (2009) Polymer-based non-vira gene delivery as a concept for the treatment of cancer. Pharmacol Rep 61: 993-999. [Crossref]

29. Vega MM, Rivas MC, Verde SJ, Oranday CA, Rubio MME, Núñez GMA, et al. (2013) Antimicrobial activity of five plants from Northern Mexico in medically important bacteria. African J Micro Res 7: 5011-5017.

30. Mahmoudi M, Ebrahimzadeh MA, Dooshan A, Arimi A, Ghasemi N, et al (2014) Antidepressant activities of Sambucus ebulus and Sambucus nigra. Eur Rev Med Pharmacol Sci 18: 3350-3353. [Crossref]

31. Roschek BJr, Fink RC, McMichael MD, Li D, Alberte RS (2009) Elderberry flavonoids bind to and prevent H1N1 infection in vitro. Phytochem 70: 1255-1261.

32. Serkedjieva J, Manolova N, Zgórniak-Nowosielska I, Zawilinska B, Grzybek J (2006) Antiviral activity of the infusion (SHS-174) from flowers extracts of Sambucus nigra L., aerial parts of Hypericum perforatum L., and roots of Saponaria officinalis L. against influenza and herpes simplex viruses. Phytother Res 4: 97-100.

Copyright: (C2017 Castillo-Maldonado I. This is an open-access article distributed under the terms of the Creative Commons Attribution License, which permits unrestricted use, distribution, and reproduction in any medium, provided the original author and source are credited. 